УДК 349.3

DOI https://doi.org/10.32837/apdp.v0i86.2445

О. П. Сорока

\title{
ПОНЯТТЯ І СУТНІСТЬ МОРАЛЬНОЇ ШКОДИ, ЗАВДАНОЇ ВТРАТОЮ ЗДОРОВ’Я ПРАЦІВНИКІВ УНАСЛІДОК НЕЩАСНИХ ВИПАДКІВ ТА ПРОФЕСІЙНИХ ЗАХВОРЮВАНЬ
}

Постановка проблеми. Життя та здоров'я людини визнаються сучасними правовими державами, в тому числі і Україною, найвищими соціальними цінностями. Враховуючи, що основним видом зайнятості в нашій країні є трудові відносини, можна констатувати, що дуже велика кількість осіб перебуває під впливом виробничих ризиків, які завжди супроводжують зазначені відносини та можуть призвести до негативних наслідків як для здоров'я, так і для життя фізичних осіб.

Закон України «Про загальнообов'язкове державне соціальне страхування» містить норми, які визначають зміст соціального захисту працівника внаслідок настання нещасного випадку на виробництві чи професійного захворювання. Основу такого (змісту) становлять страхові соціальні виплати та послуги. Водночас відповідний законодавчий акт закріплює положення про відшкодування працівникові моральної шкоди, завданої нещасним випадком чи професійним захворюванням. На відміну від раніше чинної редакції цього Закону, згідно із якою відшкодування моральної шкоди належало до страхових соціальних виплат, обов'язок виконати які покладали на Фонд соціального страхування від нещасних випадків, сьогодні моральну шкоду, заподіяну працівникові під час виконання ним трудових обов'язків, має відшкодувати роботодавець (поза системою загальнообов'язкового державного соціального страхування). Змінився також порядок відшкодування моральної шкоди працівнику, адже для врегулювання відповідних відносин застосовують чинні норми цивільного законодавства.

Мета статті полягає у з'ясуванні поняття і сутності моральної шкоди, завданої втратою здоров' я працівників внаслідок нещасних випадків та професійних захворювань.

Аналіз останніх досліджень і публікацій. Питання моральної шкоди здебільшого досліджували вчені-цивілісти І. Забара, С. Клім, Н. Полішко, С. Селезень, I. Майстер, Л. Ольховик, у роботах котрих сформульовано поняття «моральна шкода», обгрунтовано відмінності цієї шкоди від немайнової та визначено її розмір. $\mathrm{V}$ наукових розробках учених-трудовиків (Н. Болотіна, Г. Чанишева, О. Коробков) наявні спроби проаналізувати порядок відшкодування моральної шкоди, завданої працівникові внаслідок порушення роботодавцем трудових прав працівників. Однак відшкодування моральної шкоди працівнику, заподіяної нещасним випадком на виробництві та професійним захворюванням, має певні особливості, які дотепер не були розглянуті у науковій літературі, що істотно впливає на ефективність реалізації працівниками своїх трудових прав у цій сфері відносин. 
Виклад основного матеріалу. Як один із способів захисту порушених прав інститут моральної шкоди привертав і продовжує привертати увагу дослідників і практиків. Погляди на нього і до цього часу продовжують різнитися, попри те, що питання його актуальності та особливостей застосування досить часто розглядалися в іноземній і вітчизняній юридичній літературі.

Перш ніж звернутися до грунтовного аналізу правової категорії «моральна шкода», вважаємо за необхідне зупинитися на характеристиці терміна «шкода» як первісної категорії щодо досліджуваного поняття й саме через призму цієї базової категорії виявити в подальшому особливості моральної шкоди, завданої втратою здоров'я працівників внаслідок нещасних випадків та професійних захворювань. Попри те, що термін «шкода» є міжгалузевою категорією, як загальнотеоретичних, так і галузевих досліджень цього інституту у праві недостатньо. У законодавстві й досі немає легальної дефініції поняття «шкода», хоча цим терміном оперують у багатьох галузях права, коли йдеться про умови, причини й наслідки юридичної відповідальності.

Найбільш повно сутність терміна «шкода» відбиває його тлумачення, запропоноване M.С. Малеїним: «шкода може бути визначена як наслідок посягання на суспільні відносини, як наслідок порушення охоронюваних законом прав та інтересів держави, організацій, громадян» [1, с. 5]. Це поняття розуміється фахівцем як «негативні наслідки, виражені у вигляді пошкодження, псування, збитку (речового або морального), порушення немайнових прав особи або її власності. При цьому людині може бути заподіяна як матеріальна, так і нематеріальна (моральна) шкода. Остання буде виявлятися в порушенні психічного благополуччя, душевної рівноваги особистості потерпілого. У результаті вчиненого правопорушення потерпілий зазнає різні негативні почуття (приниження, роздратування, гнів, сором, відчай), фізичний біль, ущербність, дискомфорт» [2, с. 33].

Розглядаючи шкоду як наслідок негативних діянь, особливо відзначимо соціальний складник цього явища. Будь-яке неправомірне діяння, що завдає або спричиняє шкоду, є порушенням суспільних відносин, охоронюваних за допомогою норм права. Через заподіяння шкоди учасник правовідносин позбавляється можливості або обмежується в реалізації охоронюваного законом блага. Отже, нанесення шкоди праву, благу або свободі конкретної особи становить собою в широкому сенсі заподіяння шкоди суспільству загалом. Адже блага, права та свободи закріплені державою у відповідному законодавчому акті, а конкретна особа є їі громадянином, членом суспільства, на якого поширюється дія державно-нормативних приписів і морально-етичних норм. Проте соціальний складник шкоди нерозривно пов'язаний з юридичним: якщо блага не охороняються законом, навіть видимі соціальні наслідки не можуть бути підставою для відшкодування шкоди. Ці складники шкоди - юридичний і соціальний - співвідносяться як форма (норма права) і зміст (індивідуальні, громадські або суспільні відносини, охоронювані цією нормою права). Тобто в широкому розумінні шкода становить собою комплексне соціально-правове поняття, зміст якого складається з негативних наслідків діяння, що применшує, порушує або припиняє реалізацію встановлених та охоронюваних законом благ, прав і свобод. 
Розглядаючи поняття «шкода» в об'єктивному й суб'єктивному значеннях, слід спиратися на взаємозв'язок соціального і юридичного елементів шкоди. Під шкодою в об'єктивному розумінні маються на увазі негативні наслідки, які законодавець установив і конкретно визначив у тексті нормативно-правового акта. Шкода в суб'єктивному значенні розглядається як сприйняття негативних наслідків діяння самим потерпілим, оскільки ступінь фізичних і моральних страждань від одного й того ж діяння в різних осіб може бути неоднаковим. 3 поняттям шкоди в суб'єктивному розумінні тісно пов’язана її класифікація на фізичну, моральну й матеріальну (майнову).

Слід зазначити, що й до цього часу немає єдиного підходу до визначення поняття моральної шкоди як на науковому рівні, так і в законодавстві. Поняття «моральна шкода» $з$ позицій загальної теорії права виступає інститутом захисту морального інтересу особи й розуміється як фізичні або моральні страждання й обмеження (позбавлення), спричинені особі неправомірними діями правопорушника. Науковці під моральною шкодою мають на увазі (а) моральні або фізичні страждання, заподіяні діями (бездіяльністю), що посягають на належні громадянинові від народження або в силу закону нематеріальні блага (життя, здоров’я, гідність, ділова репутація, недоторканність приватного життя, особиста й сімейна таємниця тощо) або порушують його права особисті немайнові (на користування своїм ім'ям, право авторства, на охорону результатів інтелектуальної діяльності), або майнові як громадянина [3, с. 24]; (б) протиправне приниження (або замах на приниження) гідності людини, яке викликає в її психіці негативні процеси і стани. Вона полягає саме у втратах, тих негативних наслідках немайнового характеру, які виникли через страждання. Наприклад, певні зміни в житті особи: 1) неможливість реалізовувати свої звички, бажання; 2) погіршення стосунків у колективі, в сім’ї; 3) втрата роботи, можливості зробити кар'єру; 4) втрата довіри близьких людей, довіри потенційних контрагентів за договорами тощо. Душевні страждання, яких особа зазнає внаслідок посягання на її особисті немайнові чи майнові права і блага, можуть виявлятися у збентеженості, страхові (припустимо, за подальшу долю сім'ї, кар'єри, майна), переживаннях, хвилюваннях, емоційному неспокої тощо. Як наслідок, особа втрачає можливість приймати правильні рішення, продовжувати звичний для неї спосіб і режим існування. Ці зміни примушують особу докладати додаткових зусиль для організації свого життя, вони є показниками наявності моральної шкоди [4, с. 63]; (в) моральні переживання у зв'язку із втратою родичів, неможливістю продовжувати активне громадське життя, втратою роботи, розкриттям сімейної або лікарської таємниці, поширенням відомостей, що не відповідають дійсності й ганьблять честь, гідність чи ділову репутацію громадянина, тимчасовим обмеженням або позбавленням будь-яких прав тощо [5, с. 275].

Уперше законодавець згадує поняття моральної шкоди в Преамбулі до Закону України «Про реабілітацію жертв політичних репресій в Україні» від 17 квітня 1991 р., де зазначається про прагнення держави в особі Верховної Ради «...забезпечити посильну на цей час компенсацію матеріальної і моральної шкоди, заподіяної незаконними репресіями, реабілітованим та їхнім сім'ям...». Однак у цьому нормативному акті не дається визначення моральної шкоди [6, с. 31]. У Конституції 
України містяться лише окремі статті $(32,56,62,152)$, в яких згадується моральна шкода, але не розкривається її сутність. Водночас у Цивільному кодексі України законодавець визначає поняття «моральна шкода» через перелік обставин, у яких виражається моральна шкода. Так, відповідно до ч. 2 ст. 23 моральна шкода полягає: у фізичному болю та стражданнях, яких фізична особа зазнала у зв'язку з каліцтвом або іншим ушкодженням здоров'я; у душевних стражданнях, яких фізична особа зазнала у зв'язку з каліцтвом або іншим ушкодженням здоров'я; у душевних стражданнях, яких фізична особа зазнала у зв'язку зі знищенням чи пошкодженням їі майна; у приниженні честі та гідності фізичної особи, а також ділової репутації фізичної та юридичної особи [7].

Заслуговує на увагу поняття моральної шкоди, що надається у ст. 4 Закон України «Про порядок відшкодування шкоди, завданої громадянинові незаконними діями органів дізнання, досудового слідства, прокуратури і суду», де зазначається, що моральною шкодою визнаються страждання, заподіяні громадянинові внаслідок фізичного чи психічного впливу, що призвело до погіршення або позбавлення можливостей реалізації ним своїх звичок і бажань, погіршення відносин з оточуючими людьми, інших негативних наслідків морального характеру [8].

Відповідно до п. 3 Постанови Пленуму Верховного Суду України «Про судову практику в справах про відшкодування моральної (немайнової) шкоди» під моральною шкодою належить розуміти втрати немайнового характеру внаслідок моральних чи фізичних страждань або інших негативних явищ, заподіяних фізичній чи юридичній особі незаконними діями або бездіяльністю інших осіб. Вона може проявлятися у приниженні честі, гідності, престижу або ділової репутації, моральних переживаннях у зв'язку з ушкодженням здоров'я, у порушенні права власності (в тому числі інтелектуальної), прав, наданих споживачам, інших цивільних прав, у зв'язку з незаконним перебуванням під слідством і судом у порушенні нормальних життєвих зв'язків через неможливість продовження активного громадського життя, порушенні стосунків з оточуючими людьми, у разі настання інших негативних наслідків [9].

Як бачимо, під час визначення поняття «моральна шкода» здебільшого акцент робиться саме на стражданнях, які поділяються на фізичні та моральні (психічні). Фізичні страждання розглядають як фізичний біль, функціональний розлад організму, зміни в емоційно-вольовій сфері, інші відхилення від звичайного стану здоров'я, які є наслідком дій (бездіяльності), що посягають на немайнові блага або майнові права громадянина. Фізичні страждання також можуть бути і не пов'язані з органічними ушкодженнями, якоюсь хворобою чи травмою. Отже, моральна шкода, завдана втратою здоров'я працівників внаслідок нещасних випадків та професійних захворювань, - це сукупність моральних та/або фізичних страждань особи.

Згідно із законодавством України працівник, який постраждав унаслідок настання нещасного випадку на виробництві чи професійного захворювання, може звернутися до суду за захистом своїх прав щодо відшкодування моральної шкоди з вимогами до роботодавця. При цьому моральна шкода відшкодовується працівникові безпосередньо роботодавцем за таких умов: (а) за наявності факту 
порушення роботодавцем законних прав працівника; (б) у разі виникнення у працівника моральних страждань або втрати нормальних життєвих зв'язків, або виникнення необхідності для працівника додаткових зусиль для організації свого життя; (в) за наявності причинного зв'язку між попередніми умовами. Ці обставини повинні бути належно доведені, однієї заяви на підставі змісту ст. 237-1 КЗпП України не достатньо для стягнення з власника моральної шкоди. Закон не перешкоджає стягненню з власника моральної шкоди за відсутності його вини, якщо є юридичні факти, що складають підставу обов’язку власника відшкодувати моральну шкоду.

Висновки. Підводячи підсумок вищевикладеному, слід констатувати, що моральну шкоду, завдану втратою здоров'я працівників внаслідок нещасних випадків та професійних захворювань, запропоновано розуміти як сукупність моральних та/або фізичних страждань особи, яких вона зазнала у зв'язку з каліцтвом або іншим ушкодженням здоров'я; це втрати немайнового характеру, які породжують в особи, яка зазнала цих втрат, право на їх відшкодування. Моральна шкода, будучи негативним наслідком нещасного випадку чи професійного захворювання, виражається в моральних втратах потерпілого, порушенні його нормальних життєвих зв'язків, які вимагають від нього додаткових зусиль для організації свого життя. Під час визначення її характеру і ступеня необхідно виходити із суб'єктивних (індивідуальних) особливостей потерпілого і сприйняття ним негативних наслідків заподіяння такої шкоди.

Відшкодування моральної (немайнової) шкоди потерпілим від нещасних випадків на виробництві або професійних захворювань і членам їхніх сімей у зв'язку з внесеними змінами в Закон України «Про загальнообов'язкове державне соціальне страхування» вже не є страховою виплатою, а Фонд соціального страхування України звільнено від відшкодування потерпілому моральної шкоди, яка отримала професійне захворювання з наступною втратою працездатності або була понівечена на виробництві. Наразі відшкодувати моральну шкоду, завдану працівникові внаслідок професійного захворювання на виробництві, зобов’язаний роботодавець. Обов’язок роботодавця відшкодувати моральну шкоду працівникові вважаємо логічним, адже саме він є гарантом безпечних та нешкідливих умов праці, відповідає за охорону праці на виробництві. При цьому тягар аргументації та формування доказової бази заподіяння моральної шкоди і її розміру лягає на працівника, якому така шкода була заподіяна. За умови доведеності заподіяння йому моральної шкоди суди задовольняють його вимоги і присуджують відшкодування завданої моральної шкоди. Хоча і до цього часу неврегульованими залишаються питання щодо визначення розміру відшкодування моральної шкоди, а в судовій практиці бракує єдиного підходу до нього. 


\section{Jimepamypa}

1. Малеин Н.С. Возмещение вреда, причиненного личности. Москва : Юрид. лит., 1965. 230 с.

2. Малеин Н.С. О моральном вреде. Государство и право. 1993. № 3. С. 32-40.

3. Бойко М.Д. Відшкодування шкоди: правовий аспект : навч.-практ. посіб. Київ : Атіка, 2007. $328 \mathrm{c}$.

4. Петренко В. Поняття та зміст моральної шкоди за чинним законодавством. Підприємництво господарство і право. 2019. № 4. С. 60-64.

5. Шимон С.І. Цивільно-правові способи захисту конституційних прав людини (до поняття моральної шкоди). Конституція України - основа подальшого розвитку законодавства. 1997. С. 273-276.

6. Паліюк В.П. Відшкодування моральної (немайнової) шкоди : монографія. Вид. 2-е, випр. та доп. Київ : Право, 2000. 272 с

7. Цивільний кодекс України від 16.01.2003 р. № 435-IV. URL: http://zakon2.rada.gov.ua/laws/ show/435-15n.

8. Закон України «Про порядок відшкодування шкоди, завданої громадянинові незаконними діями органів дізнання, досудового слідства, прокуратури і суду» від 01.12.1994 p. № 266/94-BP. URL: http://zakon2.rada.gov.ua/laws/show/266/94- \% D0\% B2\% D1\% 80.

9. Про судову практику в справах про відшкодування моральної (немайнової) шкоди: постанова Пленуму Верховного Суду України від 31.03.1995 p. № 4. URL: https://ips.ligazakon.net/document/ view/VS95027?_ga=2.212333713.427232104.1593875141-1453711892.1566494565.

\section{Анотація}

Сорока О. П. Поняття і сутність моральної шкоди, завданої втратою здоров'я працівників унаслідок нещасних випадків та професійних захворювань. - Стаття.

Стаття присвячена дослідженню поняття і сутності моральної шкоди, завданої втратою здоров'я працівників внаслідок нещасних випадків та професійних захворювань. Моральну шкоду, завдану втратою здоров'я працівників внаслідок нещасних випадків та професійних захворювань, запропоновано розуміти як сукупність моральних та/або фізичних страждань особи, яких вона зазнала у зв'язку з каліцтвом або іншим ушкодженням здоров'я; це втрати немайнового характеру, які породжують в особи, яка зазнала цих втрат, право на їх відшкодування. Моральна шкода, будучи негативним наслідком нещасного випадку чи професійного захворювання, виражається в моральних втратах потерпілого, порушенні його нормальних життєвих зв'язків, які вимагають від нього додаткових зусиль для організації свого життя. Під час визначення ії характеру і ступеня необхідно виходити із суб'єктивних (індивідуальних) особливостей потерпілого і сприйняття ним негативних наслідків заподіяння такої шкоди.

Зазначено, що відшкодування моральної (немайнової) шкоди потерпілим від нещасних випадків на виробництві або професійних захворювань і членам їхніх сімей у зв'язку з внесеними змінами в Закон України «Про загальнообов'язкове державне соціальне страхування» вже не є страховою виплатою, а Фонд соціального страхування України звільнено від відшкодування потерпілому моральної шкоди, яка отримала професійне захворювання з наступною втратою працездатності або була понівечена на виробництві. Наразі відшкодувати моральну шкоду, завдану працівникові внаслідок професійного захворювання на виробництві, зобов'язаний роботодавець. Обов'язок роботодавця відшкодувати моральну шкоду працівникові вважаємо логічним, адже саме він $є$ гарантом безпечних та нешкідливих умов праці, відповідає за охорону праці на виробництві. При цьому тягар аргументації та формування доказової бази заподіяння моральної шкоди і її розміру лягає на працівника, якому така шкода була заподіяна. За умови доведеності заподіяння йому моральної шкоди суди задовольняють його вимоги і присуджують відшкодування завданої моральної шкоди. Хоча і до цього часу неврегульованими залишаються питання щодо визначення розміру відшкодування моральної шкоди, а в судовій практиці бракує єдиного підходу до нього.

Ключові слова: працівник, роботодавець, моральна шкода, здоров'я, нещасний випадок, професійне захворювання. 


\section{Summary}

Soroka $O$. P. The concept and essence of moral damage caused by loss of health of workers due to accidents and occupational diseases. - Article.

The article is devoted to the study of the concept and essence of moral damage caused by loss of health of workers due to accidents and occupational diseases. The moral damage caused by the loss of health of workers due to accidents and occupational diseases is proposed to be understood as a set of moral and / or physical suffering of a person, which he suffered in connection with an injury or other damage to health; these are losses of a non-material nature, which give rise to the right of the person who has suffered these losses to their compensation. Moral harm, being a negative consequence of an accident or occupational disease, is expressed in the moral loss of the victim, the disruption of his normal life relationships, which require him to make additional efforts to organize his life. In determining its nature and degree, it is necessary to proceed from the subjective (individual) characteristics of the victim and his perception of the negative consequences of causing such damage.

It is noted that compensation for moral (non-pecuniary) damage to victims of accidents at work or occupational diseases and their family members in connection with the amendments to the Law of Ukraine "On Compulsory State Social Insurance" is no longer an insurance payment, and the Social Insurance Fund Ukraine's insurance is exempt from compensating the victim for non-pecuniary damage who received an occupational disease with subsequent disability or was maimed at work. At present, the employer is obliged to compensate the moral damage caused to the employee as a result of an occupational disease at work. We consider the obligation of the employer to compensate the moral damage to the employee logical, because it is he who is the guarantor of safe and harmless working conditions, is responsible for labor protection at work. In this case, the burden of argumentation and the formation of the evidence base of non-pecuniary damage and its size falls on the employee to whom such damage was inflicted. Subject to proof of non-pecuniary damage, the courts satisfy his claims and award compensation for non-pecuniary damage. Although the issue of determining the amount of compensation for non-pecuniary damage remains unresolved, there is a lack of a unified approach to it in judicial practice.

Key words: employee, employer, moral damage, health, accident, occupational disease. 